IZA DP No. 4209

No Room to Live:

Urban Overcrowding in Edwardian Britain

Ian Gazeley

Andrew Newell

June 2009 


\title{
No Room to Live: Urban Overcrowding in Edwardian Britain
}

\author{
Ian Gazeley \\ University of Sussex \\ Andrew Newell \\ University of Sussex \\ and IZA
}

Discussion Paper No. 4209

June 2009

IZA

P.O. Box 7240

53072 Bonn

Germany

Phone: +49-228-3894-0

Fax: +49-228-3894-180

E-mail: iza@iza.org

\begin{abstract}
Any opinions expressed here are those of the author(s) and not those of IZA. Research published in this series may include views on policy, but the institute itself takes no institutional policy positions.

The Institute for the Study of Labor (IZA) in Bonn is a local and virtual international research center and a place of communication between science, politics and business. IZA is an independent nonprofit organization supported by Deutsche Post Foundation. The center is associated with the University of Bonn and offers a stimulating research environment through its international network, workshops and conferences, data service, project support, research visits and doctoral program. IZA engages in (i) original and internationally competitive research in all fields of labor economics, (ii) development of policy concepts, and (iii) dissemination of research results and concepts to the interested public.
\end{abstract}

IZA Discussion Papers often represent preliminary work and are circulated to encourage discussion. Citation of such a paper should account for its provisional character. A revised version may be available directly from the author. 


\section{ABSTRACT}

\section{No Room to Live: Urban Overcrowding in Edwardian Britain}

We study the extent of overcrowding amongst British urban working families in the early 1900s and find major regional differences. In particular, a much greater proportion of households in urban Scotland were overcrowded than in the rest of Britain and Ireland. We investigate the causes of this spatial distribution of overcrowding and find that prices, especially rents and wages are the proximate causes of the phenomenon. In large cities, ports and cities specialising in old heavy industries high rent and overcrowding are more prevalent. Within cities, but not between cities, variations in infant mortality are clearly correlated with measures of overcrowding. All the findings are consistent with a coreperiphery view of urban households choosing the location and size of housing to balance the health risks of overcrowding against the risks associated with lower and less regular incomes in places where rents are lower.

JEL Classification: $\quad$ I10, N33, R12

Keywords: $\quad$ poverty, rent, overcrowding, Scotland, 1904, infant mortality, Bowley

Corresponding author:

Andrew Newell

Department of Economics

University of Sussex

Falmer, Brighton BN1 9SN

United Kingdom

E-mail: a.t.newell@sussex.ac.uk

\footnotetext{
* The household-level data which are employed in this paper were found by the Archivist of the Library of the University of Bangor, Mr E. W. Thomas, in response to our questions about another of his holdings. We thank him and his team for all their help with this project. We also thank Gemma Mills and Theresa Jennings for invaluable research assistance and the Nuffield Foundation for their Social Science Small Grant SGS/1220, which funded the translation of the data into spreadsheet form.
} 


\section{No Room to Live:}

\section{Urban Overcrowding in Edwardian Britain ${ }^{2}$}

\section{Introduction}

It is sometimes forgotten that the early social investigators were as concerned about the housing conditions of working people as they were about the prevalence of income poverty. There was no simple relationship between the spatial distributions of wages and overcrowding (defined as more than two persons per room) in early twentieth century Britain. For example, according to a 1905 Board of Trade enquiry into wages, prices and rents in British and Irish towns and cities, overcrowding coexisted with moderately good wages in Scotland as well as low wages in Ireland. ${ }^{3}$ Edwardian Britain and Ireland experienced massive variations in overcrowding from under two per cent of working class households in towns as diverse as Crewe, Derby, Grimsby, Ipswich, Lincoln, and Portsmouth, to over 50 per cent in Glasgow and Dundee.

The health consequences of overcrowding were the subject of much contemporary concern. For example, in his famous study of York, Rowntree (1901) quoted Haw (1900):

Overcrowding causes debility. The air is vitiated, and the people herd in their unhealthy beds, in their unhealthy rooms, in their unhealthy slums, and become languid and worn out. They go about with a jaded and a spiritless air. ${ }^{4}$

\footnotetext{
${ }^{2}$ We give thanks to Peter Scott who offered a great deal of his expertise on British housing and provided detailed comments on an earlier version of this article. The usual disclaimer applies. ${ }^{3}$ British Parliamentary Papers (1908a), Report of an Enquiry by the Board of Trade into Working Class Rents, Housing, and Retail Prices, Together with the Standard Rates of Wages Prevailing in Certain Occupations in the Principal Industrial Towns of the United Kingdom (London: HMSO, 1908), Cd 3864 .

${ }^{4}$ Haw, 1900, p59.
} 
In particular, the relationship between infant mortality and overcrowded housing conditions was the subject of public debate. To introduce the main issues, we discuss the case of Glasgow. Chart 1.1 shows a strong association between infant mortality and the proportion of one-room apartments across Glasgow’s districts. Contemporary investigators were in no doubt about the direction of causality:

Glasgow stands alone with the highest death-rate, the highest number of persons per room, the highest proportion of her population occupying oneapartment houses, and the lowest occupying houses of five apartments and upwards... These facts prove beyond doubt that the predominant factor in the health of cities is the proportion of house-space to inhabitant. ${ }^{5}$

Chart 1.1: Infant mortality and overcrowding in the districts of Glasgow in 1881

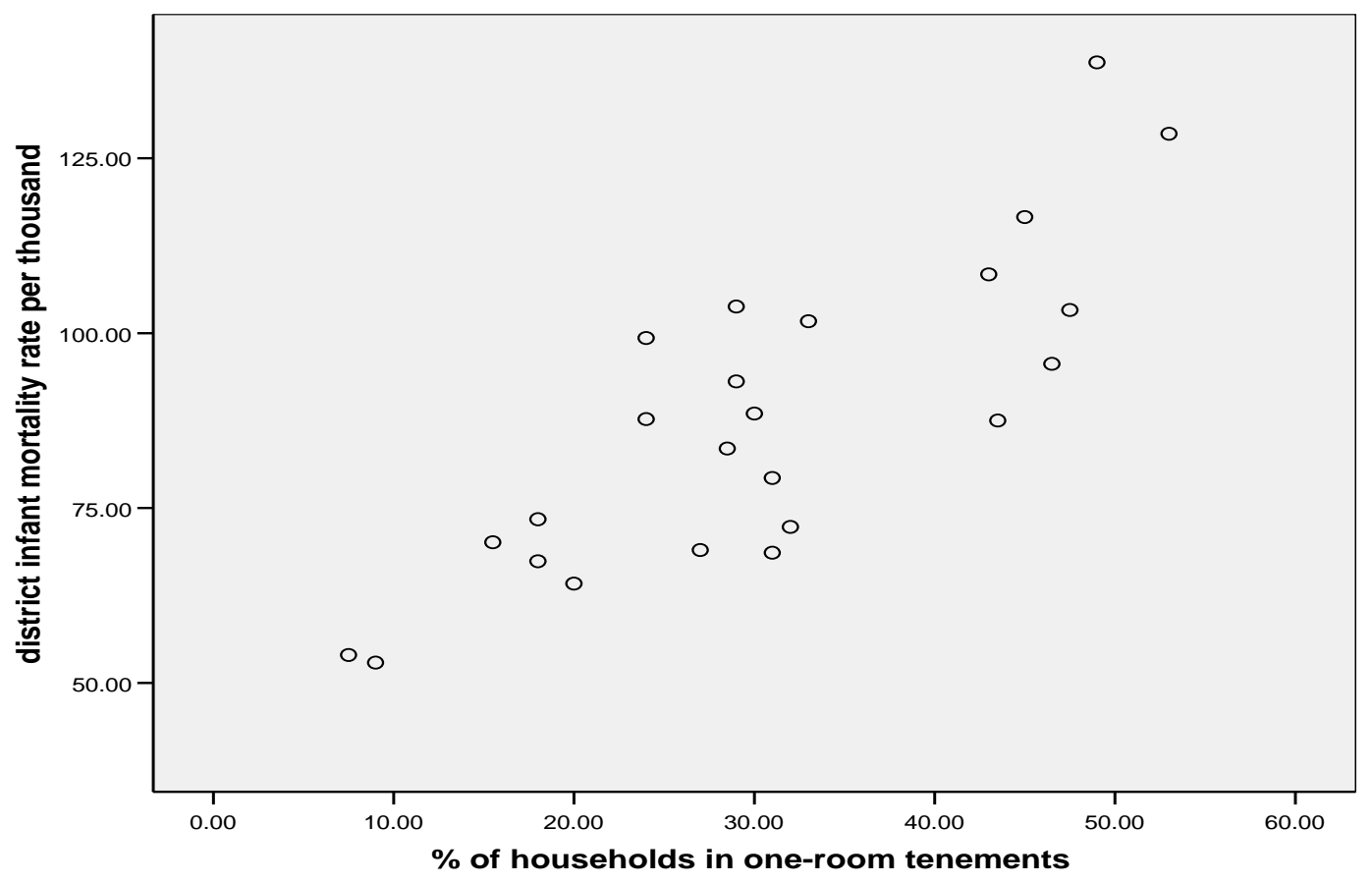

Source: Gibb, A. (1983), Table 6.v., page 131. Data originally compiled from Russell (1886).

Glasgow's high incidence of overcrowding had its roots in large-scale migration and rapid economic development, especially in the second half of the nineteenth century. Scottish property and tenancy laws may have been contributing factors. Glasgow’s

\footnotetext{
${ }^{5}$ Russell, J. B. (1887) 'The House in Relation to Public Health', Transactions of the Insurance and Actuarial Society of Glasgow, $2^{\text {nd }}$ series, No. 5, p11, quoted in Gibb (1983) , p136.
} 
population growth was probably the most rapid in Britain, making it the fourth largest city in Europe by the early 1900s: 'By 1914 no fewer than 700,000 people resided within three square miles of Glasgow Cross and created the most densely populated, central-urban area in Europe’ (Pacione, 1979, p297).

We provide a comparative statistical analysis of rents, wages and overcrowding among Britain’s cities at the turn of the twentieth century. In simple economic theory overcrowding is a consequence of a combination of high rents and low and/or uncertain wages. These can coexist in a spatial, or migration, equilibrium if the labour market advantages of agglomeration, such as higher (than outside) wages, or a greater likelihood of finding work balance the disadvantages of overcrowding. It is a very similar phenomenon, from an economic perspective, to shanty towns in developing countries.

The paper is organised as follows. Section 2 examines the distribution of overcrowding across British cities. It also discusses the particularities of the Scottish market for housing. Section 3 is a theoretical discussion from which we derive an empirically estimable model of overcrowding. We also discuss a core-periphery model of the spatial distribution of income-rent ratios, and explain how overcrowding can be thought of the result of a trade-off between the competing risks of ill-health due to overcrowding and impoverishment due to low wages or uncertain employment. In Section 4 we use data from the Board of Trade 1905 enquiry (hereafter BoT1905) to estimate our model of overcrowding and a model of the wage to rent ratio across the industrial towns and cities of Britain in 1905. Section 5 investigates the 
overcrowding-mortality relationship across British cities and across London's districts. Section 6 is a conclusion.

We find that the variation in overcrowding across British cities is well explained by variations in the ratio of wages to rent, which in turn is partially explained by city size and industrial mix. Cities based on old staple industries, which industrialised earlier, and large cities that experienced rapid population growth in the latter half of the $19^{\text {th }}$ century tend to have lower wage to rent ratios. Our investigation into the overcrowding-infant mortality relationship confirms a positive relationship within cities, but no such simple relationship between cities. It seems likely that variations in other, unobserved variables, such as health and sanitation regimes, mask the relationship between cities. We establish the within-city correlation by taking a closer look at the districts of London. We find they conform to the national picture inasmuch as rents and overcrowding are correlated. Additionally, infant mortality and overcrowding are also correlated. These districts show illustrate agglomeration effects, as overcrowding is concentrated in predominantly working class, but high rent, districts close to the city centre. 


\section{Overcrowding in Britain in the Edwardian period.}

Chart 2.1 illustrates that there was a strong regional pattern in urban overcrowding in Edwardian Britain. The chart shows how Scottish cities exhibited the highest levels of overcrowding, followed by some Irish cities and cities in the North-East of England. The chart also shows the broadly positive association between overcrowding and the affordability of housing, measured by the ratio of the weekly rent for a three-roomed dwelling to the weekly wage of a building labourer.

Chart 2.1 Overcrowding, wages and rents in Britain and Ireland in 1905

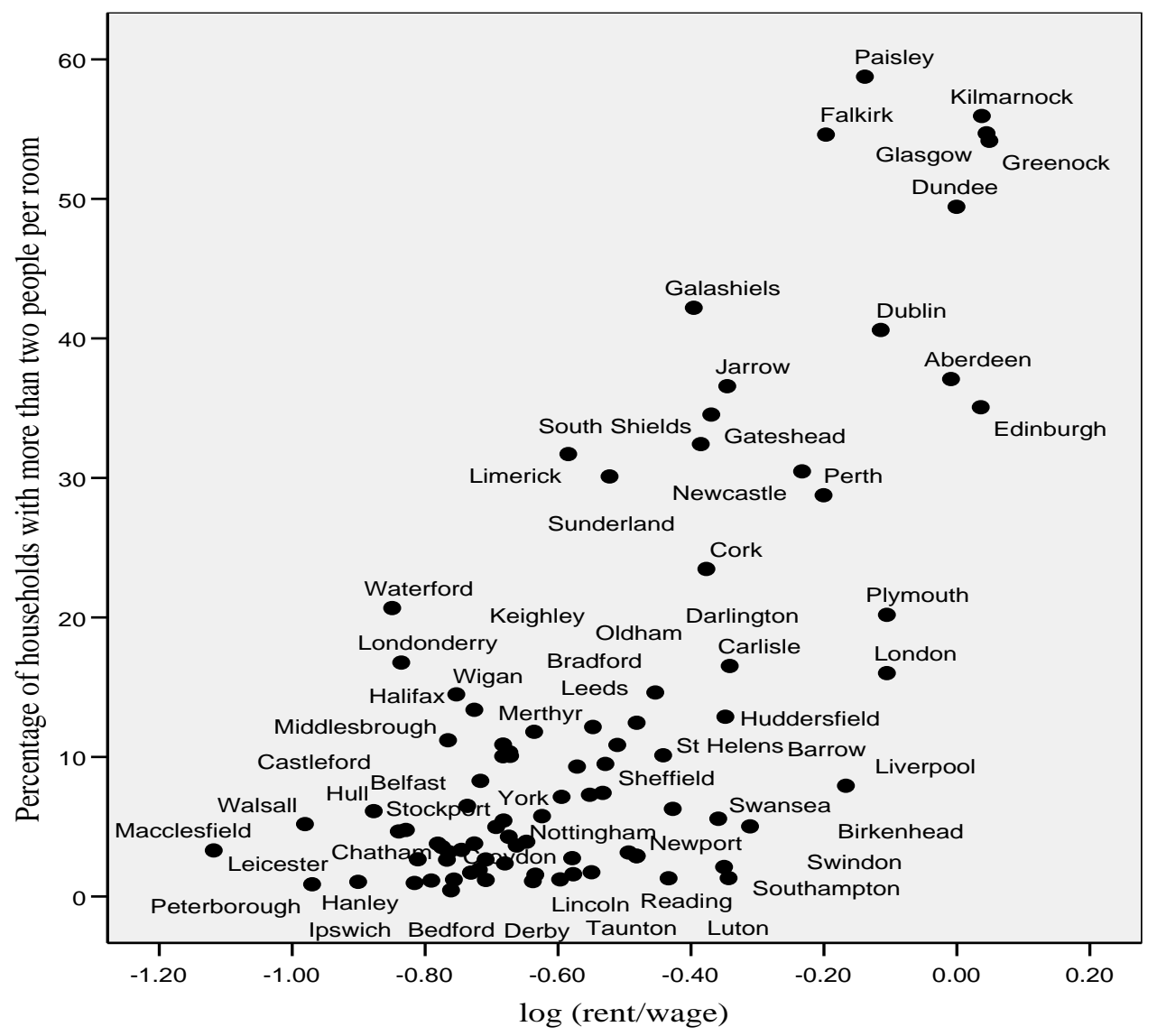

Source: British Parliamentary Papers (1908a). These data are averages. Some cities, London most obviously, will show large variation across districts. We discuss variations across districts in London later in this paper.

Table 2.1 makes clear that it is differences in the numbers of rooms in dwellings, rather than in family sizes, behind this regional pattern of overcrowding. The data set 
from which the table is generated is comprised of the recovered records from the 1904 Board of Trade enquiry into the cost of living for working class households. The results of the enquiry were published in Cd 2337; see Gazeley and Newell (2007) for a full discussion. In the last two rows of the table we see that the distribution of the number of people in households is very similar across the regions that comprised Britain at the time. In contrast, the number of occupied rooms per household ranges from an average of 5.5 in the Midlands to an average of 2.5 among Scottish households. In the Scottish sample, almost 88 percent of households lived in three or fewer rooms, while among the sample from the rest of Britain and Ireland, this figure was only 19 percent.

Table 2.1: Summary of the distributions of accommodation and households in BoTR

\begin{tabular}{|c|c|c|c|c|c|}
\hline $\begin{array}{l}\text { Percentage of } \\
\text { households living } \\
\text { in accommodation } \\
\text { comprising: }\end{array}$ & Midlands & $\begin{array}{l}\text { North of } \\
\text { England }\end{array}$ & $\begin{array}{c}\text { Rest of } \\
\text { England } \\
\text { and Wales }\end{array}$ & Ireland & Scotland \\
\hline One room & & & 3.8 & 8.4 & 4.2 \\
\hline Two rooms & 1.2 & 0.7 & 9.6 & 13.7 & 54.1 \\
\hline Three rooms & 3.5 & 6.3 & 9.6 & 13.0 & 29.3 \\
\hline Four rooms & 16.5 & 32.4 & 16.0 & 19.8 & 9.6 \\
\hline Five rooms & 17.6 & 23.2 & 22.4 & 19.1 & 2.0 \\
\hline Six rooms & 51.8 & 30.3 & 30.1 & 12.2 & 0.4 \\
\hline $\begin{array}{l}\text { More than six } \\
\text { rooms }\end{array}$ & 9.6 & 7.0 & 8.2 & 13.9 & 0.2 \\
\hline $\begin{array}{l}\text { Mean no. of rooms } \\
\text { (s.d) }\end{array}$ & $5.5(1.2)$ & $5.0(1.2)$ & 4.7 (1.7) & $4.3(2.0)$ & $2.5(0.9)$ \\
\hline $\begin{array}{l}\text { Mean persons per } \\
\text { household (s.d.) }\end{array}$ & $5.7(2.3)$ & $6.1(2.4)$ & $5.4(2.2)$ & $6.3(2.1)$ & $5.8(2.0)$ \\
\hline
\end{tabular}

Urban working class housing in the Midlands, Wales and Southern England were typically cottages of four to six rooms. Urban Yorkshire and some other older city centres featured smaller back-to-back cottages. In much of Tyneside the predominant house was a 'Newcastle', in which each dwelling occupied a single storey of a two- 
storey building, with separate entrances. Scotland was quite different again and housing was dominated by large tenement blocks of one, two of three-roomed apartments. $^{6}$

Why was urban Scottish housing so different from housing in the rest of Britain? In the mid-nineteenth century, the private sector was the main supplier of housing to the rapidly increasing Scottish urban population. In Glasgow 85 percent of authorised new dwellings built between 1862 and 1901 contained three or fewer rooms. ${ }^{7}$ The builders typically retained the right to a fee, the feu, in perpetuity. Some argue this feudal land tenure system lead to dense tenement development. ${ }^{8}$ However, tenements themselves, that is spatially dense housing, need not be overcrowded. Overcrowding reflects the use of building rather than the density of dwellings per hectare. Indeed, many tenements were created by converting older middle-class properties.

Rodger (1992, p115) gives a useful exposition of the standard explanation of Scottish overcrowding. It has three components. First, he argues that overcrowding was exacerbated by Scotland's relatively high rates of unemployment and underemployment, including severe problems of seasonal and cyclical unemployment. ${ }^{9}$ Under these conditions, income uncertainty could have led workers to make accommodation choices that took into account the risk of eviction for nonpayment of rent, rather than simply base the decision on earnings while in full employment.

\footnotetext{
${ }^{6}$ See Lee (2005), p. 145, Rodger (1989) p29. Scottish tenements were specifically designed for multifunctional use, as illustrated by the "bed-recesses" or "bed-closets" which were often included in kitchens so that they could be transformed into bedrooms at night; some kitchens having as many of two or three recesses. Rooms were 20-25 per cent larger in floor-space than English counterparts.

${ }^{7}$ Butt (1987)

${ }^{8}$ Rodger (1992), page 115.

${ }^{9}$ Further support for this viewpoint can be found in, Lee (2004) p. 436.
} 
Secondly, tenancy laws in Scotland worsened the impact of this risky environment, and tended to encourage tenants to choose small, low rent properties. This is because the permitted length of let differed in Scotland from the rest of the Britain. ${ }^{10}$ While weekly or monthly rentals were fairly commonplace in the rest of the British Isles, that was not so in urban Scotland, except for properties whose annual rental value was below $£ 5$. Properties valued above $£ 10$ a year, about 80 percent of the working class housing stock, were let by the year in Scotland. Properties rented at between $£ 5$ and $£ 10$ per annum were let monthly, quarterly, half-yearly or yearly. ${ }^{11}$ As the 1907 Report of Committee on Letting of Working Men's Dwellings in Scotland makes clear, the rules governing letting in Scotland were an impediment to mobility:

......occasions arise, from time to time, in a working man's life, warranting, or even requiring him, or, on this death, his family, to remove from one house to another between terms. The usual cause is change of employment, involving removal from one district of the same town to another or from one town to another. $^{12}$

Landlords were also indemnified against non-payment of rent by an urban hypothec, which gave the landlord the legal right to sell the possessions of defaulters.

Thirdly, as elsewhere in Britain, local taxes, called rates, were levied on dwellings, mostly proportional to rental value. The operation of the system of rates varied between Scotland and the rest of Britain. In Scotland, rates were levied directly on

\footnotetext{
${ }^{10}$ Roger (1989), pp. 39-40.

${ }^{11}$ Another unique feature of the Scottish market was the severe limitation, to only two days in the year, when rentals were allowed to start or finish, with the majority being yearly rentals commencing on $28^{\text {th }}$ May. This was not the case in England, where rental terms could start all year round. These dates were $28^{\text {th }}$ May and $28^{\text {th }}$ November. See British Parliamentary Papers (1907, Cd. 3715), page 3.

${ }^{12}$ Cd.3715 p.13
} 
the occupiers, and therefore not included in rent. ${ }^{13}$ These taxes were legally due on the $11^{\text {th }}$ of November each year. ${ }^{14}$ The imposition of yearly lump-sum payment of rates was seen as an exceptional financial burden on working-class households:

...payment of rates is demanded from occupiers in November, at the period of the year when work in many occupations is slackest, when expenses in the way of extra clothing and fire and light are heaviest, and such payment is demanded in one sum. ......No doubt the best class of working men look forward through the year to the incidence of the rates in the end of the year, and provide for their payment by admirable plans are not systematically followed by the average working man, who, although respectable, lives to a large extent from hand to mouth, and they are, of course, unknown among the class whose habits are bad. ${ }^{15}$

Thus in terms of rent and property-based taxes, Scottish workers were required to practise much greater medium-term financial discipline than their counterparts in the rest of Britain. These institutional differences alone generate incentives for Scottish householders to economise more intensely on space.

\section{An equilibrium model of the market for space.}

We develop this model to illustrate the fundamental relationships between demand for space, rents, wages and costs of housing production in an equilibrium setting. The model is then used derive an estimable model of overcrowding. On the demand side, we assume a representative household maximises a well-behaved utility function of per capita food consumption, $C$, and per capita space, $S .{ }^{16}$ We set the price of food at

\footnotetext{
${ }^{13}$ This only applied in the main to dwellings with a rental value in excess of $£ 4$ a year, which were the vast majority.

${ }^{14} \mathrm{Cd}$. 3715, page 4.

${ }^{15}$ Cd. 3715, page15.

16 Thus we ignore any possible economies or diseconomies of scale on the demand side.
} 
unity. The household contains $F$ people and earns $Y$ per capita ${ }^{17}$. We assume, realistically, that the rent of a unit of space, $R(S)$, is dependent on how much space is rented, so that rent increases with $S$ but at a decreasing rate so that $R^{\prime}>0$ and $R^{\prime \prime}<0$. The instantaneous per capita budget constraint is, in terms of food is

$$
C+R(S)=Y
$$

If we adopt Cobb-Douglas utility with $\alpha$ as the food share parameter and write the rent function as $R=R_{0} S^{\beta}$, where $R_{0}>0$ is a constant and $\beta(0<\beta<1)$ is the elasticity of rent with respect to space, then the household's Marshallian demand for per capita space is:

$$
S^{d}=\left(\frac{Y}{R_{0}\left[1+\frac{\alpha \beta}{1-\alpha}\right]}\right)^{1 / \beta},
$$

Here increases in $R_{0}, \alpha$ and $\beta$ all lower $S^{d}$. A market demand function can be developed from (2) in a number of ways, depending upon the application. The most general way forward would be to sum (2) over a population with distribution of per capita income. Note, though, that the actual rent paid by a household is endogenous, even if the parameters of the rent-size relationship for a locality are exogenous.

The supply of living space is modelled as follows. Imagine a developer planning a building of unit size. If all dwellings in the building are identical, $S$, the size of a dwelling in the building, is the inverse of $N$, the number of dwellings contained in the building. Let the building cost $P K(S)$ to erect, where $P$ is the local land price and the construction cost function $K$ is such that $K^{\prime}<0$ and $K^{\prime \prime}<0$, so that costs and marginal

\footnotetext{
17 This model is easily extended to introduce income and/or food expenditure uncertainty in a way that would be relevant to comparing Scottish behaviour with that of the rest of the British Isles, given the different operation of rental markets. This is discussed further below.
} 
costs are increasing in the number of dwellings in a building. For simplicity we assume no depreciation, no maintenance costs and the expectation that rental price will stay constant into the future. Then the expected profits, $\pi$, from the building are $\pi=\sum_{t}(1+r)^{t} \tilde{R}(S)-P K(S)$, Here $\tilde{R}(S)=R(S) / S=R_{0} S^{\beta-1}$ is the unit of space rent function. Profits are which is maximised ${ }^{18}$ where

$\widetilde{R}_{S}=r P K_{S}$,

In the long run, if the rate of profit in housing tends to some global rate of time preference, $r^{*}$, then we might expect the long-run rent to be

$\widetilde{R}=r^{*} P K$,

The first main point of this section is that in the long run, the profile of rents for dwellings of different sizes is determined completely by the profile of production costs. To see this, take the ratio of (3) and (4) and find

$$
\frac{S \widetilde{R}_{S}}{\widetilde{R}}=\beta-1=\frac{r}{r^{*}} \frac{S K_{S}}{K}
$$

Now, if we assume $r=r^{*}$, then $\beta$, the elasticity of $R$ with respect to $S$, is determined in the long run by the elasticity of $K$ with respect to $S$. In other words, the shape of the rent relationship with respect to size is determined by the shape of the building costs function and is exogenous to demand. It follows that local variations in building methods or in property-based taxes will show up in variations in the size profile of rents.

\footnotetext{
${ }^{18}$ A maximum is guaranteed by our assumptions about the $R$ and $K$ functions.

${ }^{19}$ Again, how market supply is developed from (3) and (4) depends upon the application. One could perhaps sum over building plots of different sizes and values. In a further development, land prices could be made endogenous.
} 
To develop (2) in way that is suitable for our city data, we first log-linearise and then sum over the population to create a city-wide density for $S$. To arrive at a relationship between observables, we then approximate this density with a function $f\left(\mu, \sigma^{2}, \varepsilon\right)$ where $\mu$ and $\sigma^{2}$ are the city-wide mean and variance of the log of $Y / R_{0}$, the income to rent ratio, and $\varepsilon$ is the size elasticity of rent for the city. ${ }^{20}$ The proportion of overcrowded households in a city is the integral over the city population of this density, up to the overcrowding level of $S$. Linearising, we derive the following estimating equation across the $J$ cities:

$$
\text { overcrowding }_{j}=\beta_{0}+\beta_{1} \mu_{j}+\beta_{2} \sigma_{j}^{2}+\beta_{3} \varepsilon_{j}+u_{j} \quad j=1 \ldots J .
$$

We expect $\beta_{1}$ to be negative and $\beta_{3}$ to be positive as high or more steeply rising rents will reduce demand for space and increase overcrowding. We expect $\beta_{2}$ to be positive given $\mu$, as greater income inequality will raise the variance of $S$ in a city and thus raise overcrowding. $u_{j}$ is an error term.

Two further questions require theoretical discussion. First, we need to discuss what causes spatial variation in the wage to (base) rent ratio, $Y / R_{0}$. Secondly, we need to lay out our view as to why demand for space in some locations drives rents so high as to make people choose levels of overcrowding that risk the health of their families. We sketch our answers to both questions without recourse to formal models, using basic principles from economic geography. For the first question we imagine an urban

\footnotetext{
${ }^{20}$ Logically, the elasticity, $\varepsilon$ could also have a within-city variance, but this seems unlikely, and we could not estimate it, so we omit it from the discussion.
} 
setting in which there is a greater spatial density of jobs at the economic centre than in the periphery. In world without uncertainty but taking into account the pecuniary and time costs of travel to work, rents closer to the centre will be driven up to the point where workers are indifferent between locations. So, low $Y / R_{0}$ will occur near the centre for employment. Note also that, holding everything else constant, the greater the gap in the spatial density of jobs between the core and the periphery, the greater will be the rent to wage ratio and the incidence of overcrowding at the core. An alternative way of thinking would be to allow jobs everywhere, but also hypothesise that economies of agglomeration raise wages or job opportunities closer to the centre. Again, this model also predicts low equilibrium $Y / R_{0}$ at the centre.

What about the health and other risks associated with overcrowding? In order to discuss these we need to expand the model and add uncertainty about the income stream from work and uncertainty about health outcomes like infant mortality. If dwellings in a more central location offer the potential of higher and possibly more regular income, thus lowering the risk of an episode of impoverishment, but also, via higher rents, raise overcrowding and the risk of family ill-health, then a household must decide how to balance those risks. Our model of overcrowding can be interpreted as the result of such decisions, that is, as a representation of households' responses to the competing risks of impoverishment and ill-health. 


\section{Evidence from the 1905 Board of Trade Enquiry}

In what follows we exploit the BoT1905 data on mortality rates, population, wages rates by skill, the cost of living, rents and housing conditions to understand more fully the pattern of overcrowding in Britain and Ireland. Table 4.1 illustrates the differences between Scottish cities and those in Northern England in terms of wages and rents. The table shows that money rents are 20 to 30 percent higher in Scotland than in northern England, whereas unskilled construction workers money wages are 17 percent lower. As a consequence the unskilled wage to rent ratio in Scotland is much lower. Secondly note that the skilled construction worker's wages in the two regions are a lot more similar. It is tempting to speculate that the influx of unskilled labour in the mid- $19^{\text {th }}$ century lowered the unskilled wage in Scotland ${ }^{21}$, and we offer some empirical evidence that is consistent with this hypothesis below.

Table 4.1 Size of dwellings, average rents, wages and consumer prices in Scotland and the North of England.

\begin{tabular}{|c|c|c|c|}
\hline & $\begin{array}{l}\text { Scotland } \\
\text { (10 cities) }\end{array}$ & $\begin{array}{l}\text { North of England } \\
\text { (35 cities) }\end{array}$ & Ratio \\
\hline Weekly rent for two rooms (pence) & 47.1 & 39.9 & 1.18 \\
\hline Weekly rent for three rooms (pence) & 68.7 & 51.4 & 1.34 \\
\hline $\begin{array}{l}\text { Percentage share of one and two room } \\
\text { dwellings in total occupied stock }\end{array}$ & 53.9 & 10.5 & \\
\hline $\begin{array}{l}\text { Skilled construction workers' wage } \\
\text { index }\end{array}$ & 90.6 & 87.5 & 1.04 \\
\hline $\begin{array}{l}\text { Unskilled construction workers' wage } \\
\text { index }\end{array}$ & 73.5 & 88.8 & 0.83 \\
\hline Consumer price index & 101.9 & 93.9 & 1.09 \\
\hline
\end{tabular}

Notes (1) Source: BOT1905. (2) All indices relative to London=100. (3) The rent index reflects the relative cost of a three room dwelling.

We estimate our overcrowding model using these data. Equation (5) of Section 3 is a linear model that relates the degree of overcrowding to $\mu$ and $\sigma^{2}$, which are the city-

\footnotetext{
${ }^{21}$ Of course the host market impact of immigration flows is still disputed territory in labour economics, see Erhenberg and Smith (2009, p344).
} 
wide mean and variance of the $\log$ of the income to rent ratio $Y / R_{0}$, and to $\varepsilon$, the size elasticity of rent for a city:

$$
\text { overcrowding }_{j}=\beta_{0}+\beta_{1} \mu_{j}+\beta_{2} \sigma_{j}^{2}+\beta_{3} \varepsilon_{j}+u_{j} \quad j=1 \ldots J .
$$

In the 1905 cities data, the Board of Trade give a measure of overcrowding, defined as the proportion of the population living more than 2 people to each room. Our measure of $\mu$ is the log of ratio of the index of building labourer's wages to the rent for a three-roomed dwelling. ${ }^{22}$ Our measure of the elasticity of the rent function, $\varepsilon$, is constructed for each city from the rent data for dwellings of different sizes. ${ }^{23}$ The only income variables consistently available for all the cities are the wages of skilled craftsmen and labourers in the construction industry. We use the log of the ratio of skilled workers' wages to labourers' wages as a proxy for $\sigma^{2}$.

Table 4.2. Modelling overcrowding in British and Irish cities Dependent variable: Proportion of dwellings with more than two people per room

\begin{tabular}{lcc}
\hline Explanatory variable: & $(1)$ & $(2)$ \\
\hline Log (building labourer's wage/mean rent & $-0.36(5.7)$ & $-0.40(5.5)$ \\
for a 3-room dwelling), $\mu$ & & \\
Elasticity of rent function, $\varepsilon$ & $0.095(1.5)$ & $0.14(2.1)$ \\
Log skill premium in construction, $\sigma^{2}$ & $0.30(2.4)$ & $0.23(1.8)$ \\
& & \\
$\mathrm{N}$ & 89 & 85 \\
R-squared & 0.62 & 0.63 \\
Root MSE & 0.095 & 0.094 \\
Method of estimation & OLS & IV \\
\hline
\end{tabular}

Notes. The sample comprises British and Irish industrial towns and cities in 1905. Observations are weighted by the square root of population. t-statistics are calculated with robust standard errors in brackets. For the estimation in column (2), real wages, population in 1861, population growth since 1861 and regional and industrial dummies were used as instruments for the wage to rent ratio. The sample size changes in Column (2) due to a lack of 1861 population data for Barrow, Galashiels, Jarrow and Normanton.

\footnotetext{
${ }^{22}$ In BoT1905 we are given the upper and lower limits of the range of rents for dwellings of different sizes. Three- and four-roomed dwellings are the most frequently reported. Our measure of the rent for a three-room dwelling is the midpoint of the range for cities where these rents are reported and the predicted value of this for cities where rents for three-room dwellings are not reported.

${ }^{23}$ We simply calculate average percentage changes in rents between accommodations of different sizes.
} 
The results are given in Table 4.2. The coefficients are all of the expected sign and do not vary much with the method of estimation. This quite simple specification accounts for a large amount of the spatial variation in British urban overcrowding. In Table 4.3 we report our investigation into Scotland's intense overcrowding, by comparing the actual and estimated rates of overcrowding for 10 Scottish cities with those for 35 Northern English towns. Scottish cities have overcrowding rates that are on average 35 percentage points higher than those in Northern England. Using the coefficients from column (2) of Table 4.2, we find that about sixty percent of this gap is explained by differences in the wage to rent ratio, with the differences in size elasticities and skill differentials making much smaller contributions.

Table 4.3 Decomposing the overcrowding gap between Scottish Cities and those in the North of England

\begin{tabular}{lc}
\hline & Scotland minus North of England \\
\hline Total overcrowding gap in percentage points & 35.4 \\
Due to difference in & 21.4 \\
$\quad$ Wage/rent ratio & 2.5 \\
$\quad$ The size elasticity of rents & 6.1 \\
$\quad$ The skill differential & 29.0 \\
Total estimated & 6.4 \\
Residual gap & \\
\hline Notes. We used the coefficients from Table 4.2, column (2) to perform this decomposition. See text for \\
a further explanation of the method.
\end{tabular}

Table 4.4 contains the results of the last investigation of this section. Here, the question is whether some structural features for which we have measures can account for variations in the wage-rent ratio. In Column (1) the variables at our disposal explain about half the variation in the ratio, and they tell a convincing, if partial, story. Larger cities have lower wage-rent ratios. Though wages tend to be higher in larger cities, rents tend to higher still. A higher skill premium is also associated with higher 
rents, relative to the unskilled wage. The last group of variables reflect industrial structure. Cities in which old heavy industries, such as mining and shipbuilding, dominate, as well as ports, tend to have lower wage-rent ratios. The most obvious rationale is that accommodation in these cities tended to be concentrated in relatively small geographical areas close to the place of work such as a deep harbour or coalfield. Referring back to our theoretical discussion, these can be thought of as places where the spatial density of jobs at the core is high. But also, these cities tend to be those that developed earlier, when real incomes, and the demand for space, was lower, so smaller dwellings were built. Cities specialising in newer manufacturing industries, which mostly developed later and in which the core may be more diffuse, tend to have higher rent-wage ratios.

All these findings are confirmed in the regression reported in Column 2 of Table 4.4. In that regression we add indicator variables for Scotland and Ireland, as very crude proxies for the impact of the potato famines and the consequent movements of populations. Of course, institutional and other omitted differences are also captured by these proxy variables. The signs of the effects, which are positive but conventionally insignificant for Ireland and significantly negative for Scotland, are consistent with the impacts expected from these forced migrations. 
Table 4.4 Explaining the wage to rent ratio in British and Irish cities, 1905

\begin{tabular}{lcc}
\hline Explanatory variables: & $(1)$ & $(2)$ \\
\hline Log population in 1901 & $-0.080(3.5)$ & $-0.065(4.0)$ \\
Log skill premium & $-0.706(1.7)$ & $-0.624(1.5)$ \\
Chief industry: & & \\
$\quad$ Heavy: shipbuilding, mining etc. & $-0.149(2.5)$ & $-0.122(2.8)$ \\
$\quad$ Manufacturing & $0.096(1.8)$ & $0.074(1.6)$ \\
$\quad$ Port & $-0.151(1.7)$ & $-0.221(3.0)$ \\
Irish city & & $0.282(1.2)$ \\
Scottish city & & $-0.357(3.6)$ \\
& 89 & \\
Sample size & & \\
$\quad \mathrm{R}^{2}$ & 0.48 & 0.70 \\
Root MSE & 0.21 & 0.16 \\
Method of estimation & Weighted OLS & Weighted OLS \\
\hline
\end{tabular}

Notes. See notes to Table 4.2.

\section{Overcrowding and mortality}

In this section we return to the health consequences of overcrowding. We have already noted that contemporary social investigators and medical officers saw overcrowding as a serious threat to health and a particular threat to the lives of infants. Our first investigation is into the statistical relationships in the 1905 data between mortality rates and overcrowding across the towns cities of Britain. Charts 5.1 and 5.2 show the relationships between overcrowding and infant mortality and between overcrowding and the crude death rate. In both charts there is a group of towns and cities from the south and midlands of England in the bottom left corner with low death rates and low overcrowding. From that corner of each chart, the observations fan out in all directions and we find similar death rates for cities with virtually no overcrowding, for instance Luton or Portsmouth, and the heavily overcrowded Scottish cities. It seems clear there is no simple relationship. We investigated this econometrically, adding variables to control of population, real wages and regional dummies, but found no significant positive effects from overcrowding rates to 
mortality rates. ${ }^{24}$ It seems unlikely that there was indeed no relationship, and more likely that the lack of correlation derives from our exclusion, for lack of data on other variables, such as health care or hygiene regime indicators.

Chart 5.1 Infant mortality and overcrowding in British and Irish cities

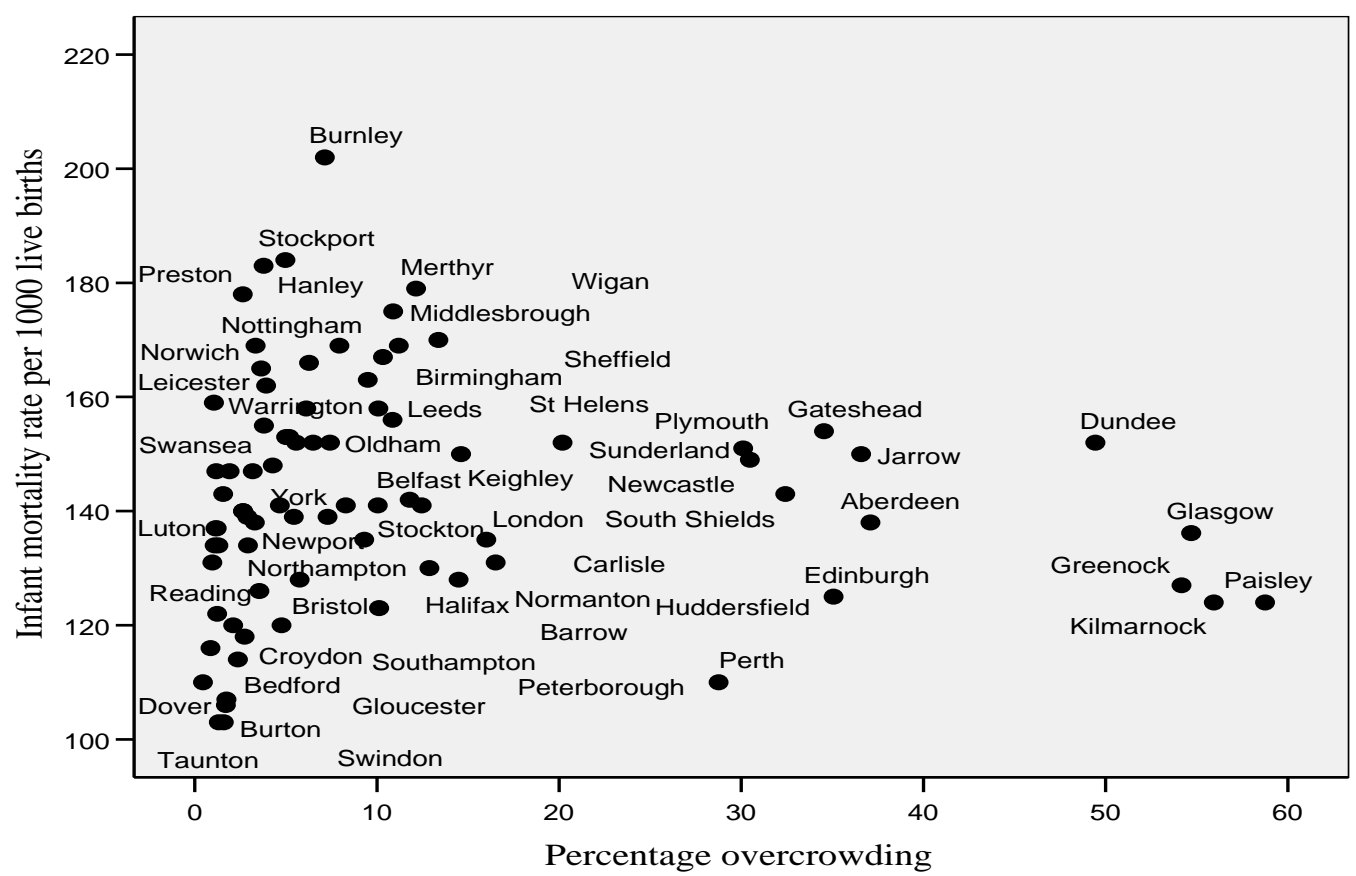

Chart 5.2 Overcrowding and the Crude Death rates in Britain

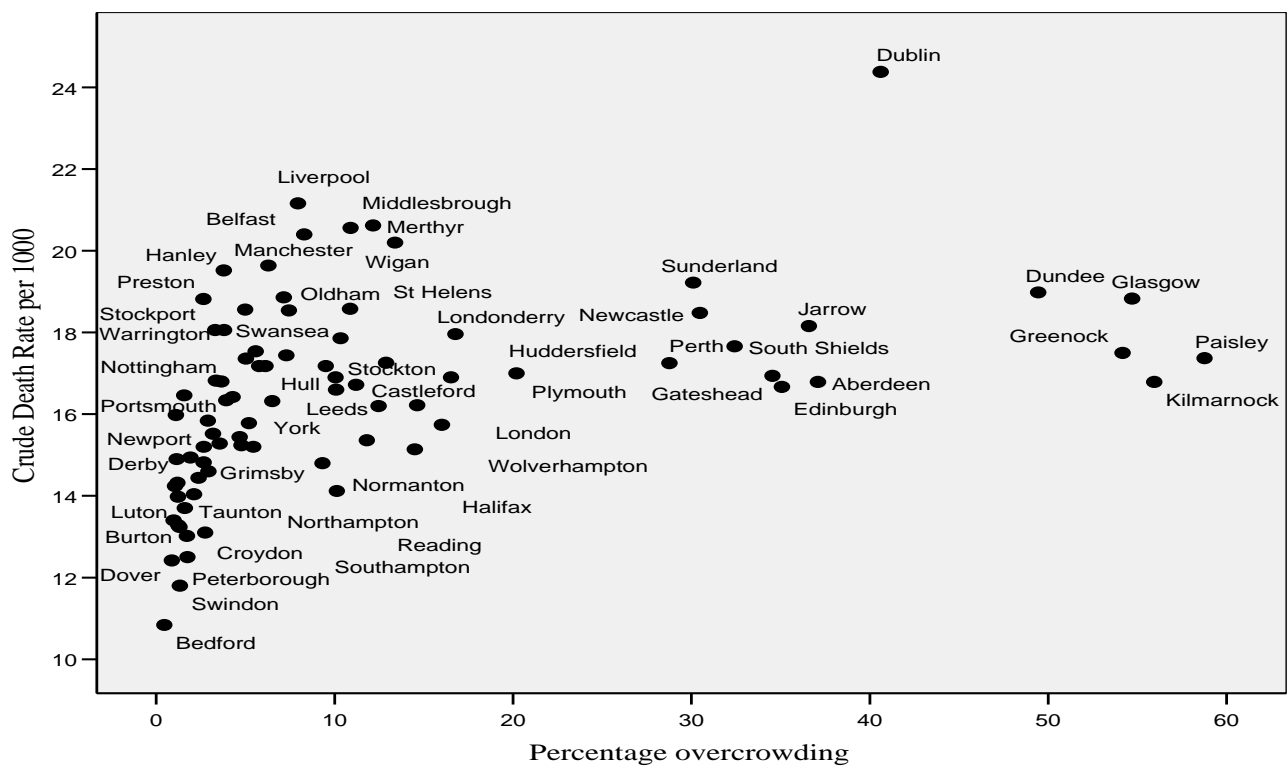

${ }^{24}$ Regression results are available from the authors on request. 
To investigate the mortality-overcrowding relationship more closely, we employ data from forty-one London districts. BoT1905 gives data for rates of overcrowding from the 1901 census, infant mortality rates for 1902 and rents for dwellings of different sizes for these districts. The overcrowding-infant mortality relationship is illustrated in Chart 5.3. As with the Glaswegian district data in Chart 1.1, there is a clear positive relationship. The high infant mortality-high overcrowding districts are some of the oldest, most industrialised districts, clustered around the City of London: Bermondsey, Bethnal Green, Finsbury, Holborn, Shoreditch, Southwark and Stepney. They were also districts with high rents, as high as those in fashionable districts like Chelsea, Marylebone and Westminster. The Board of Trade did not collect wages by district. Many of these overcrowded areas, aside from being within easy commuting distance to the City, were centres of particular industries such as carriage-making in Holborn, leather-working in Bermondsey and Southwark and jewellery and precision instruments in Finsbury. 
Chart 5.3 Infant Mortality and overcrowding across London Districts 1901-1902

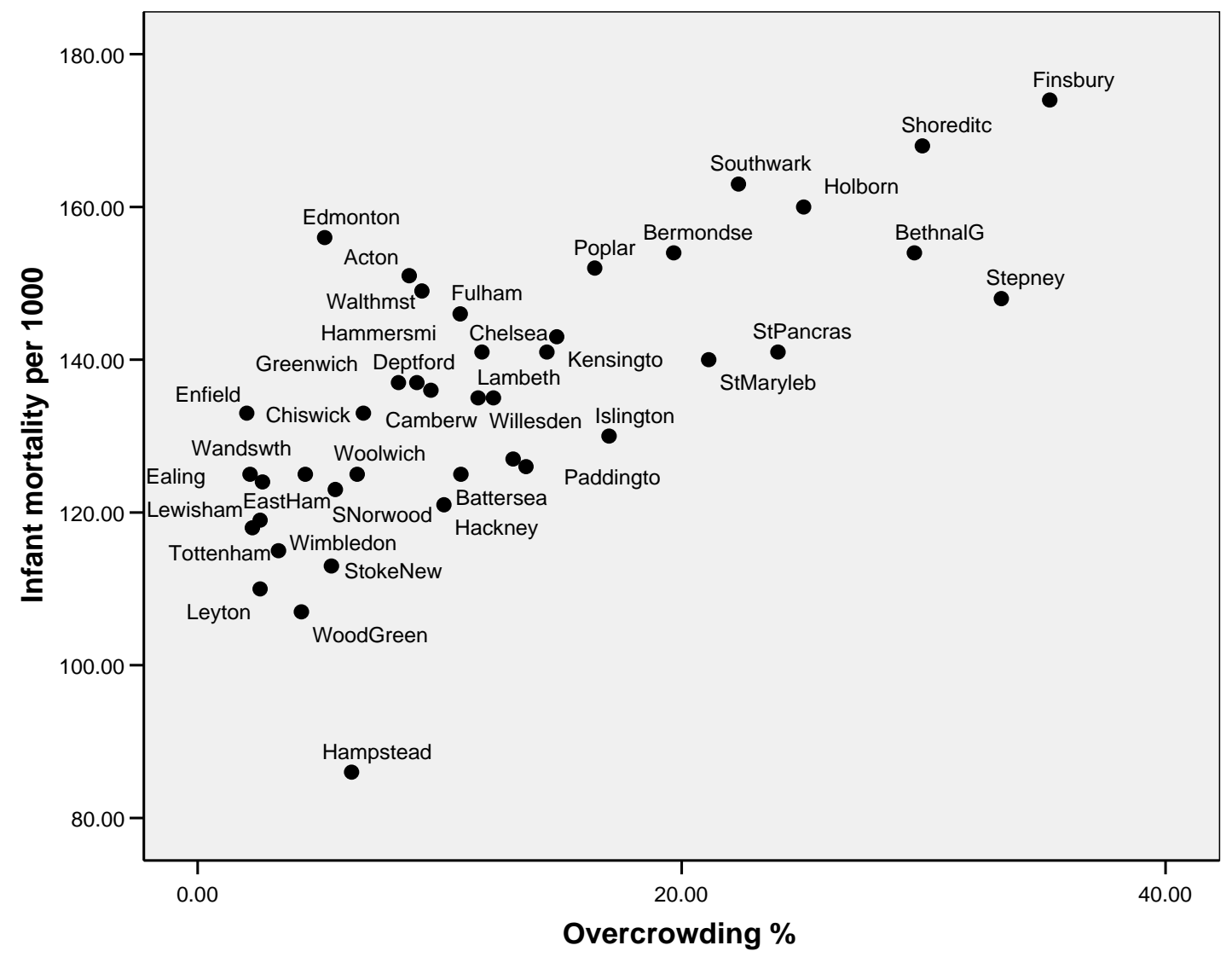

In Table 5.2 we offer two regressions that demonstrate the relationships between rents and overcrowding and infant mortality among London's boroughs. In the first column, we demonstrate a strong correlation between rents and overcrowding. Suggestively, the estimated semi-elasticity between rents and overcrowding here is very close in magnitude to that reported in Table 4.2. In other words the overcrowding-rent relationship was of a similar magnitude across London’s districts as it was across Britain's towns and cities. The relationship between rents and infant mortality is of course much noisier, but there is still a clear association. Proximity to the areas with good wages and high densities of jobs comes at a price, and for poorer families the price was to risk undermining their families' health; perhaps even to prejudice the survival chances of their children. 
Table 5.2. Overcrowding, infant mortality and rents in among London districts Dependent variable: $\quad$ Rate of Overcrowding

Infant mortality rate per 000)

\begin{tabular}{lcc} 
Log rent for 3 rooms & $0.39(5.1)$ & $32.8(1.8)$ \\
$\mathrm{R}^{2}$ & 0.40 & 0.07 \\
Root MSE & 7.05 & 17.36 \\
Sample size & 41 & 41 \\
\hline
\end{tabular}

Notes: Method of estimation, OLS

\section{Conclusion}

The paper establishes that overcrowding in Edwardian Britain was not simply a consequence of income poverty. Low wages are one part of the story and the centrifugal forces that drive people to want to live close to centres of work and result in high rents are the other main part of the explanation. We find that large towns and cities and those dependent upon older industries were the centres of overcrowding. We have shown that this can be thought of as working through the theoretically conventional impact of relative prices. City wages may be higher, but city rents are higher still. We find empirically that overcrowding and low wage to rent ratios are concentrated in large cities and in ports and cities specialising in heavy industries. Data from London's districts confirm the rent -overcrowding relationship with high rents and overcrowding co-existing in the inner city close to the commercial and industrial heart of the capital.

On the overcrowding-mortality relationship, we find a bivariate correlation within cities between cities. It is most likely that omitted variable bias obscures the 
relationship between cities. For instance, the heavy overcrowding in Scottish cities was not enough to raise crude death rates and infant mortality rates significantly above those for the rest of Britain. However, among the districts of Glasgow and those of London, where, other environmental factors, such as health provision are likely to be less variable than between cities, there is a clear positive relationship between overcrowding and infant mortality.

\section{References}

British Parliamentary Papers (1905), Consumption and the Cost of Food in Workmen's Families in Urban Districts of the United Kingdom, Cd 2337 (1905)

British Parliamentary Papers (1907), Report of the Departmental Committee on House-letting in Scotland. Vol. I., Cd. 3715 (1907)

British Parliamentary Papers, (1908a), Cost of Living of the Working Classes. Report of an Enquiry by the Board of Trade into Working-Class Rents, Housing and Retail Prices Together with Standard Rates of Wages Prevailing in Certain Occupations in Principal Industrial Towns in the United Kingdom. Cd 3864.

British Parliamentary Papers, (1908b), Returns showing the housing conditions of the population of Scotland Cd 4016

British Parliamentary Papers (1912-13), 'Cost of Living of the Working Classes. Report of an Enquiry by the Board of Trade into Working-Class Rents and Retail Prices Together with the rates of wages in Certain Occupations in Industrial Towns in the United Kingdom' Cd 6955 (1912-13)

Butt, J. (1987) 'Housing' in Cage, R.A. (ed.), The Working Class in Glasgow, 17501914, Croom Helm, Beckenham.

Erhenberg, R.G. and R. S. Smith, (2009) Modern Labor Economics, Pearson, Boston, $10^{\text {th }}$ Edition

Gazeley, I and A Newell (2007) "Poverty in Britain in 1904: an early social survey rediscovered", IZA Discussion Paper 3046, September.

Gibb, A. (1983), Glasgow: The Making of a City, Croom Helm, Beckenham. 
Haw, G. (1900), ‘No Room to Live: The Plaint of Overcrowded London’, Wells Gardner Darton and Co. London, Second Edition.

Lee, C. H. (2004) 'Scotland 1850-1939: Growth and Poverty,' in R. Floud and P. Johnson (eds), The Cambridge Economic History of Britain. Volume 2: Economic Maturity, 1860-1939, Cambridge, Cambridge University Press.

Lee, C. H. (2005) `Economic progress; wealth and poverty’, 128-59 in T. M. Devine, C. H. Lee, and G. C. Peden, The Transformation of Scotland. The Economy since 1700 (Edinburgh: Edinburgh U.P., 2005), p. 145;

Pacione, M., (1979) 'Housing Policies in Glasgow since 1880', Geographical Review, 69, 4, 395-412.

Rodger, R. (1985), 'Employment, Wages and Poverty in the Scottish Cities, 18411914', in Gordon, G. (ed.) Perspectives of the Scottish City, Aberdeen University Press.

Rodger, R. (1989), 'Crisis and confrontation in Scottish housing 1880-1914', pp. 2553 in Richard Rodger (ed), Scottish Housing in the Twentieth Century ,Leicester: Leicester University Press.

Rodger, R. (1992), 'Scotland' in Pooley, C.G. (ed.), Housing Strategies in Europe, 1880-1930, Leicester University Press.

Rowntree, B.S., (1901) Poverty: A Study of Town Life, Macmillan, London.

Russell, J.B. (1886), The Vital Statistics of the City of Glasgow, Pt. 1.

Russell, J. B. (1887) 'The House in Relation to Public Health', Transactions of the Insurance and Actuarial Society of Glasgow, $2^{\text {nd }}$ series, No. 5 